\title{
THE OLDER ADULT - HIS CONTRIBUTION TO THE COMMUNITY OF SOUTH AFRICA
}

\author{
MRS Z. DROSKIE, M. Soc. Sc. U.O.F.S.*
}

\section{SUMMARY}

Growing old involves biological, emotional and social changes. Life roles change, but will depend on personal life patterns of work and activity, relationships and attitude. There is a loss in activities requiring speed, but a gain in those requiring carefulness, thoroughness and the use of previous experience. Retirement usually results in adjusting to a low, fixed income. Accumulated skills, knowledge, judgement, wisdom and perspective are lost, yet productivity and creativity can be utilised if the older person is allowed to pursue a career pattern suitable to his needs.

\section{INTRODUCTION}

Growing old can be a critical experience because it involves biological, emotional and social changes. It has been stated that old age begins at that point in an individual's life when he ceases to perforn all those duties and enjoy all those rights which were his during mature adulthood; when he begins to take over a new system of rights and duties.

* Director of S.A. National Council for the Aged. Received 7 June 1982.

\section{OPSOMMING}

Om oud te word, behels biologiese, emosionele en sosiale veranderinge. Lewersrolle verander, maar hang nog af van $t$ persoonlike lewenspatrone van werk en aktiwiteit, verhoudinge en gesindhede. Daar is verlies van aktiwiteite wat spoed verg, maar dié wat sorgvuldigheid, deeglikheid en die gebruik van vorige ondervinding verg, word verbeter. Aftreding bring aanpassing by 'n lae, vasgestelde inkomste mee. Versamelde vaardighede, kennis, oordeel, wysheid en perspeknief word veroor, $10 \mathrm{~g}$ kan produktiwiteit en vindingrykheid benut word as die ouer persoon toegelaat word om 'n beroeps-patroon geskik vir sy behoefte te volg.

We do not know what ageing is. Consequently we cannot decisively separate the social, behavioural and biological changes, intrinsic to ageing from medical history, cultural and ethnic background, environment and all the external factors which have gone into the making of a person's life.

Life-roles change at different times and to a different degree; some end completely, others become modified. Old age is neither inherently miserable nor inherently sublime. The process of ageing and eventual death must ultimately be accepted as the natural progression of the life cycle; the old completing their prescribed lifespan and making way for the young. 


\section{CHARACTERISTICS OF THE OLDER ADULT}

Different people mature at different developmental tempos. They grow up and grow old in response to different combinations of genetic and environmental circumstances. Physiological and psychological characteristics may be as diverse within age groups as between age groups.

Sociological forces, on the other hand, are so largely functions of time periods that they confer different characteristics on different generations. Those who grew up within a particular time period have experienced the history, culture, economics and educational opportunities of that period.

The state of an elderly individual's well-being develops from his personal life pattern of work or activity, human relationships and mental attitude. Ageing is variable and no two persons will react physically, socially or emotionally in precisely the same way.

\section{CHANGE IN GOALS}

Changes take place in an older person and one of the niajor changes is characterised by a slowing down. Reaction times do slow down with age but most of the older age group fully retain until their death their ability to reason, their memory and their wit.

Research has proved that ageing is a process which amounts to a loss in those activities that require speed and disciplined teamwork but that it represents a gain in those activities which require carefulness, thoroughness and the use of previous experience.

\section{MAINTENANCE OF ECONOMIC STATUS}

It would be labouring the obvious to stress the importance of adequate income when discussing the practical realities of life for retired persons. We all know, or at least should know, that income, health care and housing for the aged is inadequate.

Retired persons in our society face one common task adjusting to living on the low income available in retirement years. With fixed incomes and rising prices the problems which centre around the financial circumstances of retired persons are overwhelming and pensioners. be they in receipt of state or private pensions, have been greatlyaffected by the rising cost of living.

There is no doubt that our economy will eventually be overwhelmingly burdened through an arbitrary and compulsory retirement age forcing one part of the population to support both the young and the old with a resultant decrease in the living standard of all.

The following chart indicates the expected increase in the number of people over the age of 60 years from 1340350 in 1970 to 5934760 by 2020 .

$\begin{array}{llrrrrr}\begin{array}{l}\text { Aged Populations - } \\ \text { Year }\end{array} & \text { White } & \begin{array}{c}\text { Age 60+ } \\ \text { Coloured }\end{array} & \text { Asian } & \text { Bantu } & \text { Total } \\ 1970 & 394600 & 99270 & 20530 & 825950 & 1340350 \\ 1980 & 508280 & 125190 & 32220 & 997390 & 1663080 \\ 1990 & 607840 & 170200 & 48240 & 1363680 & 2189960 \\ 2000 & 714920 & 249500 & 73600 & 1932030 & 2970050 \\ 2010 & 908510 & 362030 & 116140 & 27251804111860 \\ 2020 & 1107310 & 573180 & 164420 & 4089850 & 5934760\end{array}$

\section{WASTE OF HUMAN EXPERIENCE}

In our society, the attitude to retirement generally is such that once people are no longer working. their intrinsic worth is diminished.

Yet people are retired compulsorily on grounds of age. The accumulated skills, knowledge. judgement, wisdom and perspective of the older adult a re discarded just when they can be of most value to society.

Each year as thousands of people are encouraged or forced to retire, their skills, knowledge and wisdom are lost and their opportunities to inst ruct, teach, consult or advise, listen and reflect, as well as to work, are cut off.

In an era when people made their own products and were their own bosses, they used to work until they were disabled or died. Today this is still the case for the self-enıployed, who also have some control over the work they do - lawyers, physicians, farmers and the like; they continue to be productive and are apt to work to the end. Why then do we not continue to make use of the rest of the work force?

Older people begin to face age discrimination as early as age 45 , even if highly qualified. Many are forced to retire at a specific age, usually between the ages of 60 to 65 , and are told to enjoy the retirement which often means poverty as well as idleness and can result in living in isolation. People who may have truly loved to work feel empty and useless when their jobs are stripped away. Others who would welcone retirement, if they could afford it, are fighting to survive rather than enjoy the leisure to which they have looked forward.

Older people are not the only losers in all of this. We as a nation a re deprived of their varied skills and experience; a whole generation of people trained in every conceivable occupation is suddenly cut off from us. Retirement and age discrimination cause a tremendous waste of human resources. Productivity, independence and self-help are cherished values and expectations, but even if the older person is willing and able to work it is difficult for him to find a job.

\section{PRODUCTIVITY AND CREATIVITY IN OLD AGE}

Most of the old people in our country a re intellectually and socially competent. interested in their surroundings and eager to participate in family and community life. They could be immensely productive given the opportunity.

Thus we see that at the point of retirement from the work force the individual should have a variety of options to pursue in finding a career pattern suitable to his/her own needs.

Retirement should not be a hopeless condition of disengagement from all life-sectors. There can be a shift in careers during the retirement period and change in interest and physical condition are the most important factors in such changes. Provision should be made whereby the older adult can structure for himself a range of options in all lifesectors. He should have the right to nuke choices and decisions and participate in planning for his own welfare. Having a purpose in life and being socially useful are as necessary to the older adult as to anyone else.

\section{AGE DISCRIMINATION IN EMPLOYMENT}

Employers often have negative stereotyped attitudes to older job applicants, which in general have little or no basis in fact. Paradoxically employers nay be older persons themselves whose work performance belies their beliefs. Employers often justify their stereotypes and their reluctance to hire older workers with the excuse that they are in business to make profits and older workers are considered unprofitable investments. Surveys show no significant drop in performance or productivity.

Many of the older workers actually exceed the average output of the younger employees; workers 65 and over have a good record of attendance in comparison with other age groups; older workers are more flexible in accepting a change in their occupation and earnings. Yet employers are prejudiced in giving these people the opportunity to prove that they are capable of making a most important contribution to commerce and industry. 